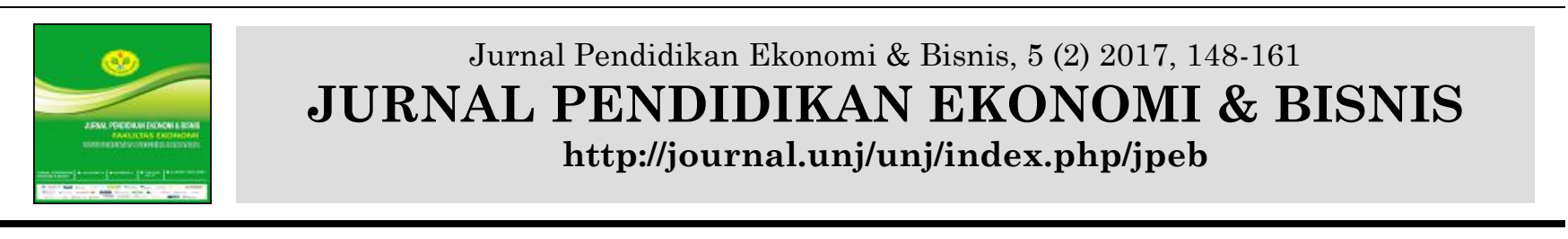

\title{
Gaya Kepemimpinan Transformasional Kepala Sekolah dan Kinerja Guru SMK Swasta di Jakarta Timur
}

\author{
Army Cahaya Putra Rustamaji ${ }^{1}$, Dedi Purwana ${ }^{2}$, Corry Yohana ${ }^{3 *}$ \\ 1 SMK Negeri 1 Jakarta, Indonesia \\ ${ }^{2}$ Fakultas Ekonomi, Universitas Negeri Jakarta, Indonesia \\ ${ }^{3}$ Fakultas Ekonomi, Universitas Negeri Jakarta, Indonesia
}

\section{Article Info}

Article history:

Received: 9 September 2017;

Accepted: 22 September 2017;

Published: 30 October 2017.

Keywords:

Transformational Leadership; Job Satisfaction; Performance

\begin{abstract}
This study aims to examine the effect of transformational leadership on teacher performance, job satisfaction and job attachment, the influence of work attachment to teacher performance, the influence of job satisfaction on teacher performance, direct influence between transformational leadership on teacher performance mediated by job satisfaction, and influence between transformational leadership of teacher performance mediated by work attachment. The result of the research shows that tranasformational leadership toward performance and job satisfaction have positive and significant influence. However, job satisfaction on teacher performance has no significant effect. Transformational leadership of performance mediated by job satisfaction shows a significant influence. Furthermore, transformational leadership towards work attachment has a positive and significant effect. Likewise on the variable attachment of work to performance. Furthermore, transformational leadership significantly affects employee performance with work attachment as a mediating variable.
\end{abstract}

\begin{abstract}
Abstrak
Penelitian ini bertujuan menguji pengaruh kepemimpinan transformasional terhadap kinerja guru, kepuasan kerja dan keterikatan kerja, pengaruh keterikatan kerja terhadap kinerja guru, pengaruh kepuasan kerja terhadap kinerja guru, pengaruh langsung antara kepemimpinan transformasional terhadap kinerja guru yang dimediasi oleh kepuasan kerja, dan pengaruh antara kepemimpinan transformasional terhadap kinerja guru yang di mediasi oleh keterikatan kerja. Hasil penelitian menunjukan variabel kepemimpinan tranasformasional terhadap kinerja dan kepuasan kerja berpengaruh positif dan signifikan. Namun kepuasan kerja terhadap kinerja guru tidak berpengaruh secara signifikan. Kepemimpinan transformasional terhadap kinerja yang di mediasi oleh kepuasan kerja menunjukan pengaruh yang signifikan. Selanjutnya Kepemimpinan transformasional terhadap keterikatan kerja berpengaruh positif dan signifikan. Begitupun pada variabel keterikatan kerja terhadap kinerja. Selanjutnya kepemimpinan transformasional berpengaruh secara signifikan terhadap kinerja karyawan dengan keterikatan kerja sebagai variabel pemediasi.
\end{abstract}

How to Cite:

Putra Rustamaji, A. C., Purwana, D., \& Yohana, C. (2017). Gaya Kepemimpinan Transformasional Kepala Sekolah dan Kinerja Guru SMK Swasta di Jakarta Timur. Jurnal Pendidikan Ekonomi \& Bisnis, 5(2), 148-161.

https://doi.org/https://doi.org/10.21009/JPEB.005.2.3

* Corresponding Author. 


\section{PENDAHULUAN}

Pendidikan di Indonesia belum memadai dan mencapai tujuan yang diharapkan. Bahkan dari segi Sumber Daya Manusia (SDM) pun dinilai belum memadai dan jauh dari hal yang dinginkan. Setiap instansi pendidikan dibutuhkan instrumen yang dapat menunjang untuk meningkatkan kinerja dan kualitas bangsa. Dari hal tersebut, diharapkan peran guru untuk dapat meningkatkan kinerjanya yang harus didukung penuh oleh kepala sekolah. Oleh karena itu, sebuah organisasi sangat memerlukan adanya suatu potensi dan kekuatan internal yang kokoh dalam rangka menghadapi semua tantangan, hambatan serta perubahan yang ada. Hal ini dikarenakan organisasi yang maju dan berkembang setiap saat mampu mengatasi masalah dengan solusi yang tepat sesuai situasi dan kondisi yang ada.

Rendahnya mutu pendidikan di Indonesia juga tercermin dari daya saing di tingkat internasional. Daya saing Indonesia menurut World Economic Forum (WEF) pada tahun 2014-2015 berada di level 74 dari 144 negara. Salah satu penyebab rendahnya mutu pendidikan di Indonesia adalah dari komponen mutu guru. Rendahnya profesionalitas guru di Indonesia dapat dilihat dari kelayakan guru mengajar.

Dalam penjabaran tersebut penulis akan melihat pada sebuah fenomena yang tampak bahwa kinerja guru di sekolah dipengaruhi oleh banyak faktor. Tabel 1 merupakan Tes Kendali Mutu SMK Swasta di wilayah Rayon 05 Jakarta Timur 1 Tahun Ajaran 2014/2015. Dengan mata pelajaran yang diujikan yaitu Bahasa Indonesia, Bahasa Inggris, dan Matematika oleh Kelompok Kerja Kepala Sekolah (K3SK) Jakarta Timur tahun ajaran 2014/2015 pada SMK Swasta di wilayah Rayon 05 Jakarta Timur 1 menunjukkan rata-rata kelulusan siswa baru mencapai $80,81 \%$ dari jumlah total seluruh siswa sebesar 1032 siswa. Maka hal ini mengindikasikan bahwa mutu pendidikan di wilayah tersebut masih rendah.

Berbagai cara dilakukan oleh pemerintah untuk mengatasi permasalahan rendahnya kinerja guru ini, seperti dengan cara mengadakan sertifikasi. Salah satu faktor yang membuat profesionalitas guru rendah adalah kehadiran atau absen. Banyak sekali guru yang menganggap bahwa kehadiran itu adalah hal kecil, padahal kehadiran merupakan salah satu tolak ukur dalam kinerja. Tabel 2 merupakan data yang diperoleh dari segi kehadiran guru.

Berdasarkan data pada tabel 2 terlihat bahwa setiap bulannya terjadi ketidakhadiran guru yang cukup banyak dibandingkan denhan karyawan sekolah secara keseluruhan. Ketidakhadiran pada jam kerja menjadi hal yang harus diperhatikan bagi pihak manajemen karena merupakan kedisiplinan kerja yang akan sangat berpengaruh pada kinerja karyawan dan hasil kerja karyawan. Salah satu faktor yang mempengaruhi kinerja guru dalam organ-

Tabel 1

Hasil Tes Kendali Mutu (TKM)

Mata Pelajaran Bahasa Indonesia, Matematika, dan Bahasa Inggris Pada SMK Swasta Di Wilayah Rayon 05 Jakarta Timur 1

\begin{tabular}{cccccc}
\hline SMK & Lulus & $\begin{array}{c}\text { \% } \\
\text { Lulus }\end{array}$ & $\begin{array}{c}\text { Tidak } \\
\text { Lulus }\end{array}$ & $\begin{array}{c}\text { \% Tidak } \\
\text { Lulus }\end{array}$ & $\begin{array}{c}\text { Jumlah } \\
\text { Siswa }\end{array}$ \\
\hline SMK Mercusuar & 319 & $87,40 \%$ & 46 & $12,60 \%$ & 365 \\
SMK Ristek Jaya & 283 & $83,24 \%$ & 57 & $16,76 \%$ & 340 \\
$\begin{array}{c}\text { SMK Pelayaran } \\
\text { Dewaruci }\end{array}$ & 37 & $64,92 \%$ & 20 & $35,08 \%$ & 57 \\
$\begin{array}{c}\text { SMK Gita Wisata } \\
\text { SMK Perbankan }\end{array}$ & 20 & $57,14 \%$ & 15 & $42,86 \%$ & 35 \\
$\quad$ Nasional & 175 & $74,47 \%$ & 60 & $25,53 \%$ & 235 \\
$\quad$ Total & 834 & $80,81 \%$ & 198 & $19,19 \%$ & 1032 \\
\hline
\end{tabular}

Sumber: Data K3SK Rayon 05 Jakarta Timur 1 
isasi atau perusahaan adalah gaya kepemimpinan.

Yukl (2013) menyatakan bahwa kepemimpinan mencerminkan asumsi bahwa hal itu melibatkan proses di mana terdapat kesengajaan dalam pengaruh yang diberikan oleh seseorang kepada orang lain yang bertujuan untuk membimbing, pengawasan struktur, dan memfasilitasi kegiatan dan hubungan dalam kelompok atau organisasi.

Selanjutnya Stoner, Freeman, dan Gilbert (1995) menyatakan bahwa kepemimpinan transformasional adalah suatu sikap yang harus dimiliki oleh pemimpin dalam hal mengrahkan bawahannya dalah hal peningktakan kinerja. Melengkapi Stoner, Freeman, dan Gilbert (1995), Griffin (2000) mengelompokkan pengertian kepemimpinan menjadi dua konsep, yaitu sebagai proses, dan yang kedua sebagai atribut. Proses kepemimpinan yang dimaksud adalah dalah hal mengarahkan dan menggerakkan bawahannya kepada tujuan organisasi.

Lebih jauh lagi, dijelaskan bahwa kepemimpinan transformasional didefinisikan sebagai sikap yang mewakili pandangan individu terhadap sikap atasan dalam mengarahkan karyawannya yang bertujuan untuk meningkatkan kinerja, mementingkan kepentingan bawahan dan anggota tim, serta memberikan sesuatu yang bawahan butuhkan seperti dalam hal memberikan penghargaan pemimpin yang memiliki jiwa transformsional akan senantiasa memberikan dan membangun komitmen dan keterikatan kerja bagi bawahan dalam rangka pencapaian tujuan organisasi. Ini dimaksudkan agar para bawahan benar-benar akan selalu mengikuti apapun arahan yang diberikan oleh pemimpin

Menurut teori Kouzes dan Posner, pemimpin transformasional adalah pemimpin yang harus mampu memberikan contoh kepada bawahannya, menjadikan panutan bagi bawahannya, dapat menginspirasikan untuk para karyawan, mengarahkan bawahan ke arah yang lebih jauh, memberikan motivasi yang kuat bagi karyawan agar kinerja karyawan tersebut bagus, serta siap untuk menerima tantangan ke depannya bagi pemimpin, karyawan serta seluruh isi di suatu organisasi. Jadi dapat dikatakan bahwa kepemimpinan transformasional dapat didefinisikan sebagai kemampuan pemimpin dalam meningkatkan kinerja karyawannya. Dengan sikap kepemimpinan yang ditunjukkan oleh kepala sekolah, maka kinerja para guru pun akan meningkat dan dengan begitu para guru akan selalu meningkatkan produktivitas kerja di sekolah tersebut.

Tabel 2

Data Absensi Ketidakhadiran Guru Periode Juli 2015 - Juni 2016

\begin{tabular}{clccccc}
\hline No. & $\begin{array}{c}\text { Nama } \\
\text { Sekolah }\end{array}$ & $\begin{array}{c}\text { SMK } \\
\text { Mercusuar } \\
\text { Jakarta }\end{array}$ & $\begin{array}{c}\text { SMK } \\
\text { Perbankan } \\
\text { Nasional } \\
\text { Jakarta }\end{array}$ & $\begin{array}{c}\text { SMK } \\
\text { Ristek } \\
\text { Jaya } \\
\text { Jakarta }\end{array}$ & $\begin{array}{c}\text { SMK } \\
\text { Pelayaran } \\
\text { Dewaruci } \\
\text { Jakarta }\end{array}$ & $\begin{array}{c}\text { SMK } \\
\text { Wisata } \\
\text { Jakarta }\end{array}$ \\
\hline 1 & Juli & 3,90 & 4,60 & 3,12 & 5,72 & 7,80 \\
2 & Agustus & 8,00 & 7,50 & 7,60 & 10,40 & 11,00 \\
3 & September & 9,24 & 9,17 & 9,24 & 24,64 & 23,10 \\
4 & Oktober & 8,40 & 9,63 & 12,60 & 24,36 & 23,10 \\
5 & November & 7,22 & 9,10 & 4,56 & 22,04 & 11,40 \\
6 & Desember & 7,92 & 9,00 & 10,44 & 18,00 & 19,80 \\
7 & Januari & 11,88 & 7,79 & 7,92 & 8,80 & 11,00 \\
8 & Februari & 5,70 & 11,08 & 8,36 & 14,44 & 14,25 \\
9 & Maret & 13,20 & 5,50 & 7,92 & 22,88 & 17,60 \\
10 & April & 11,76 & 7,88 & 11,34 & 16,80 & 18,90 \\
11 & Mei & 11,78 & 7,13 & 4,18 & 8,36 & 18,05 \\
12 & Juni & 4,80 & 4,67 & 4,48 & 8,32 & 12,80 \\
\hline \multicolumn{2}{l}{ Sumber $:$ SMK Mercusuar Jakarta, SMK Perbankan Nasional Jakarta, SMK Ristek Jaya } \\
\multicolumn{2}{l}{ Jakarta, SMK Pelayaran Dewaruci Jakarta, SMK Gita Wisata Jakarta } &
\end{tabular}


Dalam kepuasan kerja, guru akan senantiasa termotivasi akan kerjanya. Guru yang puas akan kinerjanya, cenderung menjadi seorang pekerja yang produktif. Guru demikian juga akan turut serta berkontribusi terhadap penciptaan budaya kerja yang tepat di dalam organisasi. Berdasarkan beberapa aspek di atas maka informasi terhadap peningkatan kualitas organisasi merupakan hal yang sangat menarik untuk diteliti. Kepuasan kerja akan menjadi sangat penting bagi kinerja guru di dalam sebuah organisasi karena hal ini akan memotivasi kinerja guru untuk berprestasi lebih baik lagi. Prestasi yang baik adalah representasi dari sebuah kinerja yang positif dan dapat berpengaruh terhadap baiknya kinerja organisasi.

Pada dasarnya kebutuhan hidup manusia tidak hanya berupa material, tetapi juga bersifat non material, seperti kebanggaan dan kepuasan kerja. Tiap individu cenderung akan dihadapkan pada hal-hal yang mungkin tidak diduga sebelumnya di dalam proses mencapai kebutuhan yang diinginkan sehingga melalui bekerja dan pertumbuhan pengalaman, seseorang akan memperoleh kemajuan dalam hidupnya. Kinerja adalah hasil atau tingkat keberhasilan seseorang secara keseluruhan selama periode tertentu di dalam melaksanakan tugas dibandingkan dengan berbagai kemungkinan, seperti standar hasil kerja, target atau sasaran atau kriteria yang telah ditentukan terlebih dahulu dan telah disepakati bersama.

Menurut Simamora (1997), kinerja adalah sesuatu yang sangat dibutuhkan oleh seseorang untuk mencapai ketercapaian. Sedangkan Suprihanto (Srimulyo, 1999) mengemukakan bahwa kinerja merupakan hasil yang diperoleh di dalam pekerjaan yang berupa prestasi individu ataupun kelompok dan dilakukan menurut dengan aturan dan norma yang ada. Kinerja dapat dilihat dari produktivitas kerja karyawan tersebut. Kinerja ini yang menentukan bagaimana seseorang tersebut dapat bertahan atau tidak di suatu organisasi dan akan berdampak pada keutuhan dan kelangsungan hidup suatu perusahaan.

Menurut Anggraeni dan Sentosa
(2013), kepuasan kerja merupakan suatu sikap yang berasal dari dalam diri yang bersifat individu. Dikatakan individu karena setiap karyawan memiliki tingkat kepuasan kerja yang berbeda-beda. Terkadang terdapat individu yang memiliki tingkat kepuasan kerja yang tinggi, dan juga ada yang memiliki tingkat kepuasan kerja yang rendah. Tinggi rendahnya tingkat kepuasan kerja seseorang biasanya dipengaruhi oleh banyak faktor misalnya motivasi yang tinggi, kondisi dan kenyamanan suatu organisasi, keadaan pemimpin, serta apa yang didapat di dalam organisasi tersebut.

Setiap individu yang satu dengan individu yang lain pasti akan mempunyai pandangan yang berbeda-beda tentang arti kerja. Dan kepuasan kerja sangat berpengaruh terhadap kinerja seorang karyawan. Dapat dikatakan jika seseorang memiliki tingkat kepuasan kerja yang tinggi, maka tingkat motivasi akan kerja juga tinggi, sehingga pengaruh terhadap kinerja juga tinggi. Dan sebaliknya, jika seseorang memiliki tingkat kepuasan kerja yang rendah, maka tingkat motivasi akan kerja juga rendah, sehingga pengaruh terhadap kinerja juga rendah

Konsep keterikatan kerja awalnya diperkenalkan oleh Kahn (1990). Kahn mengemukakan bahwa keterikatan kerja adalah suatu sikap yang dimiliki oleh seorang individu yang dapat berupa rasa bangga dan peduli terhadap pekerjaan yang dijalankan di suatu organisasi.

Macey, et al (2008) sampai pada kesimpulan bahwa keterikatan karyawan merupakan hubungan pikiran sesame karyawan dan kondisi psikologis yang tinggi, selalu ditunjukkan oleh karyawan dalam hal kinerja yang tinggi. Dapat dikatakan jika individu mempunyai tingkat keterikatan yang tinggi, maka rasa ingin memiliki individu tersebut terhadap oganisasi juga tinggi. Ini disebabkan karena individu memiliki rasa terikat yang sangat kuat dan memiliki rasa yang ingin selalu tetap dan mencurahkan segala usahanya untuk kemajuan organisasi.

Keterikatan kerja yang tinggi akan berpengaruh positif terhadap komitmen organisasi dalam kinerja guru. Hasil positif 
tersebut secara tidak langsung akan memberikan gambaran bagaimana kepuasan seorang guru bekerja di dalam sebuah organisasi. Jadi dapat dikatakan semakin terikat seorang guru akan pekerjaannya, maka akan semakin tinggi pula rasa ingin memiliki terhadap organisasi tersebut dan akan berpengaruh positif terhadap kinerja organisasi. Jadi jika guru itu terasa terikat dengan pekerjaannya, maka guru itu akan senantiasa bekerja secara tulus dan lebih termotivasi lagi akan kinerjanya sehingga munculnya semangat dalam bekerja itu juga akan tinggi.

Selanjutnya, berdasarkan latar belakang masalah seperti yang dipaparkan, maka perlu dilakukan penelitian yang berfokus pada kinerja guru terkait pengaruh kepemimpinan transformasional terhadap kinerja guru Sekolah Menengah Kejuruan (SMK) dengan variabel kepuasan kerja dan keterikatan kerja sebagai variabel pemediasi.

\section{METODE}

Dalam penelitian ini, banyak aspek yang harus diperhitungkan sehingga dapat tersusun secara teratur dan terstruktur. Dapat dikatakan, penelitian ini memakai rancangan penelitian dengan menggunakan penelitian pengujian hipotesis (hypothesis testing) dengan penelitian yang berbentuk penelitian kausalitas. Dalam menentukan dimensi waktu penelitian, penelitian ini melibatkan satu waktu tertentu dalam banyak sampel (cross sectional).

Adapun teknik pengumpulan data penelitian dilakukan dengan memakai kuesioner untuk melihat pengaruh variabel kepemimpinan transformasional terhadap kinerja guru yang dimediasi oleh variabel keterikatan kerja dan kepuasan kerja guru tetap SMK Swasta yang ada di Kota Jakarta Timur. Kerangka penelitian ini dapat dilihat pada gambar 1. Selanjutnya untuk analisis internal dalam penelitian ini menggunakan pendekatan Structural Equation Modeling (SEM).

Hartono (2013:146) mengemukakan bahwa validitas memnunjukkan seberapa nyata suatu pengujian mengukur apa yang seharusnya diukur. Di dalam penelitian harus diperlukan uji validitas dan uji reabilitas. Menurut Sekaran (2013) Uji reliabilitas merupakan pengujian yang dapat dilakukan untuk mendapatkan hasil berupa ketetapan data dan keseimbangan data yang digunakan dalam penelitian ini. Gambar 2 merupakan hasil

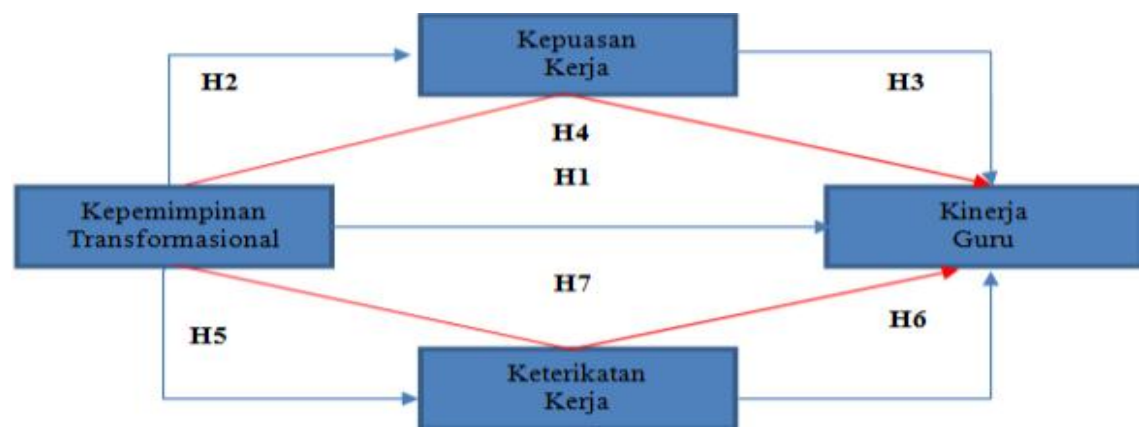

Gambar 1. Kerangka Penelitian

Tabel 3.

Evaluasi Kriteria Goodness of Fit Sebelum Respesifikasi

\begin{tabular}{llll}
\hline Kriteria & Cut-of value & $\begin{array}{l}\text { Hasil } \\
\text { Model }\end{array}$ & Keterangan \\
\hline $\begin{array}{l}\text { Khi Kuadrat } \\
\text { p-value }\end{array}$ & Besar $=3637.319$ & 0,000 & Model Kurang Baik \\
CMIN/DF & 0,05 & 4.949 & Model Kurang Baik \\
RMSEA & $\leq 2,00$ & 0.148 & Model Kurang Baik \\
GFI & $<0.08$ & 0,546 & Model kurang Baik \\
AGFI & 0,90 & 0,494 & Model kurang Baik \\
TLI & 0,90 & 0,734 & Model kurang Baik \\
CFI & 0,90 & 0,750 & Model kurang Baik \\
\hline
\end{tabular}


pemodelan struktural.

Selanjutnya dilakukan pengujian ful model dengan nilai kriteria yang digunakan dalam penelitian ini, yaitu ; Chi-square, Probability, CMIN/DF, RMSEA, GFI, AGFI, CFI, dan TLI. Hasil pengujian beberapa criteria tersebut dapat dilihat pada tabel 3 . Hasil pemerikasaan Fit of model pada tabel 3 menunjukkan bahwa dari ketujuh kriteria, ada tujuh yang menunjukkan model kurang baik, yaitu Khi Kuadrat, CMIN/DF, RMSEA, GFI, AGFI, TLI, dan CFI. Kemudian di respesifikasi sehingga mendapatkan hasil proses AMOS (gambar 3).

Hasil pemerikasaan Fit of model pada tabel 4 menunjukkan bahwa dari ketujuh kriteria, ada enam yang menunjukkan model baik, yaitu Chi-square, Probability,CMIN/ DF, RMSEA, GFI, CFI, dan TLI.

Hubungan langsung (direct effect) an- tar konstruk dari model dapat dibandingkan untuk mengevaluasi hubungan setiap konstruk terhadap pengaruh langsung yang tidak lain adalah koefisien dari semua garis koefisien dengan anak panah satu ujung (Ferdinan Augusty, 2005:55) yang hasil ujinya disajikan pada tabel 5 .

Hasil estimasi standardized regression weights, diketahui nilai koefisien pengaruh c.r (critical ratio) yang sama dengan uji t pada analisis regresi dan tingkat probabilitas masing masing hubungan langsung antara variabel laten. Tabel 5 dan gambar 3 menunjukkan lima model hubungan langsung, yaitu: (1) kepemimpinan transformasional berpengaruh signifikan terhadap kepuasan kinerja; (2) kepemimpinan transformasional berpengaruh signifikan terhadap keterikatan kerja; (3) kepua-

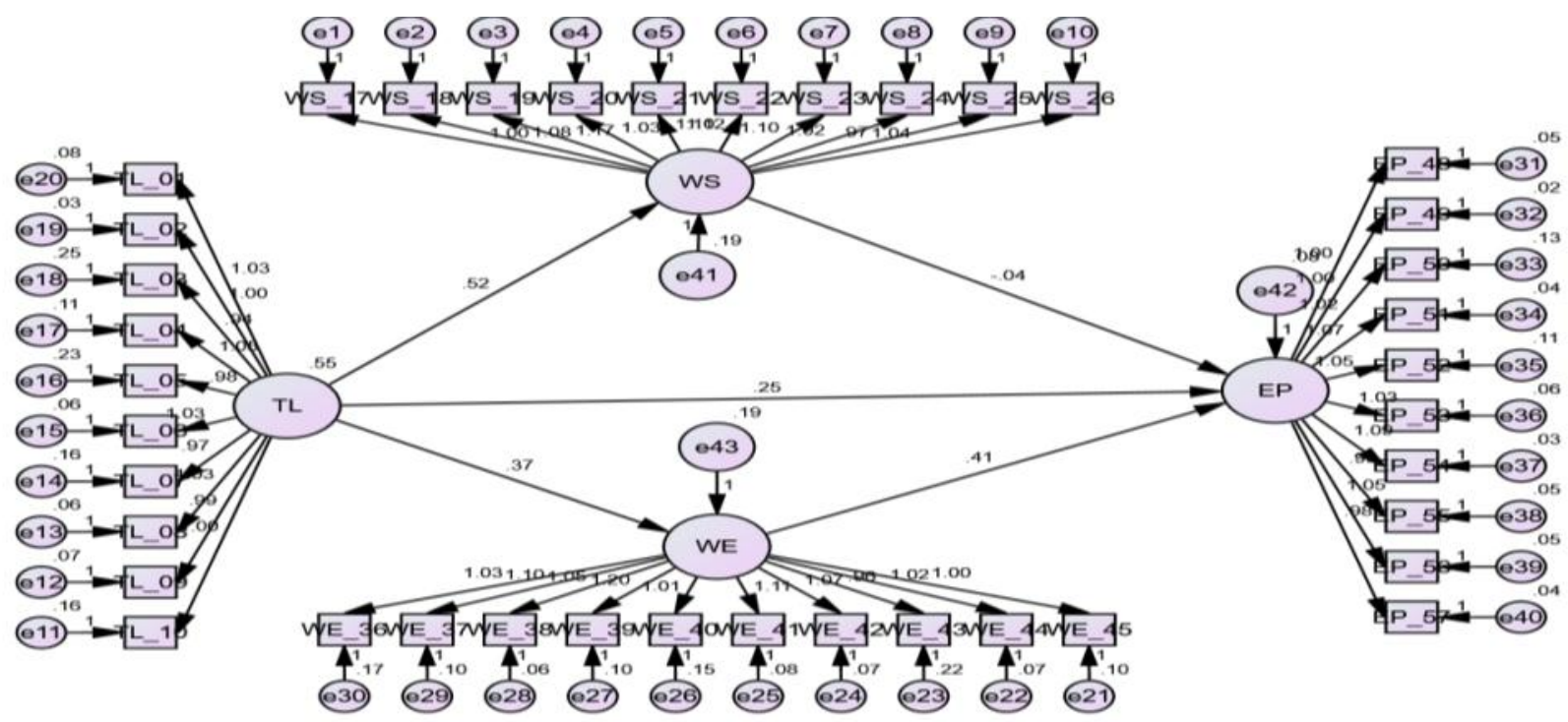

Gambar 2. Full Model Pengaruh Hubungan Antar Variabel

Tabel 4.

Evaluasi Kriteria Goodness of Fit Sesudah Respesifikasi

\begin{tabular}{llll}
\hline Kriteria & Cut-of value & $\begin{array}{l}\text { Hasil } \\
\text { Model }\end{array}$ & Keterangan \\
\hline Khi Kuadrat & Kecil $=92,172$ & 0.000 & Model Baik \\
p-value & 0,05 & 1,961 & Model Baik \\
CMIN/DF & $\leq 2,00$ & 0,073 & Model Baik \\
RMSEA & $<0,08$ & 0,926 & Model Baik \\
GFI & 0,90 & 0,878 & Model kurang Baik \\
AGFI & 0,90 & 0,972 & Model Baik \\
TLI & 0,90 & 0,980 & Model Baik \\
CFI & 0,90 & & \\
\hline
\end{tabular}


san kinerja tidak berpengaruh signifikan terhadap kinerja guru; (4) keterikatan kerja berpengaruh signifikan terhadap kinerja guru, dan (5) kepemimpinan transformasional berpengaruh signifikan terhadap kinerja guru. Hubungan yang tidak langsung kepuasan kerja dan keterikatan kerja berperang sebagai pendukung dalam memperkuat hubungan kepemimpinan transformasial terhadap kinerja disajikan pada tabel 6 .

Berdasarkan hasil gambar yang di run dengan aplikasi AMOS (gambar 3) menunjukkan bahwa tidak semua variabel memiliki pengaruh Hasil penelitian menunjukan variabel kepemimpinan transformasional terhadap kinerja berpengaruh positif dan signifikan karena memiliki nilai $\mathrm{p}$-value $\mathbf{0 , 0 0 0} \leq a \quad 0,05$. Begitupun kepemimpinan transformasional terhadap kepuasan kerja memiliki nilai nilai $p$-value $\mathbf{0 , 0 0 0} \leq \alpha \quad 0,05$ yang berarti kepemimpinan transformasional berpengaruh positif dan signifikan terhadap kepuasan kerja. Namun kepuasan kerja terhadap kinerja guru tidak berpengaruh secara signifikan dengan nilai $\mathrm{p}$ value $\mathbf{0 , 0 6 0} \geq$ a 0,05 .

Pada variabel kepemimpinan transformasional terhadap kinerja yang di mediasi oleh kepuasan kerja menunjukan pengaruh yang signifikan. Pada variabel Kepemimpinan transformasional terhadap keterikatan kerja memiliki pengaruh positif dan signifikan dengan nilai t-value sebesar $p$ -value $\mathbf{0 , 0 0 0} \leq$ a 0,05 . Begitupun pada variabel keterikatan kerja terhadap kinerja mempunyai nilai $p$-value $\mathbf{0 , 0 0 0} \leq a \quad 0,05$. Terakhir dapat dilihat variabel kepemimpinan transformasional terhadap kinerja dengan keterikatan kerja sebagai variable pemediasidan dapat diartikan variabel kepemimpinan transformasional berpengaruh secara signifikan terhadap kinerja karyawan dengan keterikatan kerja sebagai variabel pemediasi.

\section{HASIL DAN PEMBAHASAN}

Hasil statistik membuktikan bahwa hipotesis yang telah diajukan, menunjukan beberapa hipotesis terbukti memiliki pengaruh dan signifikan, sedangkan lainnya tidak memiliki pengaruh karena memiliki hasil dibawah nilai kritis t tabel yakni 0,05. Adapun pembahasannya adalah sebagai berikut:

Untuk hipotesis pertama adalah pengaruh kepemimpinan tramsformasional terhadap kinerja guru. Nilai koefisien jalur antara kepemimpinan transformasional dengan kinerja guru sebesar 0,321 dengan nilai probabilitas sebesar 0,000 . Nilai probabilitas tersebut lebih kecil dari level of signifikan yang ditetapkan $(\mathrm{p}=0,000<\mathrm{\alpha}=0,05)$. Hasil pengujian ini juga didukung oleh penelitian sebelumnya yang dilakukan oleh Abbasi dan Zamani-Miandashti (2013) yang

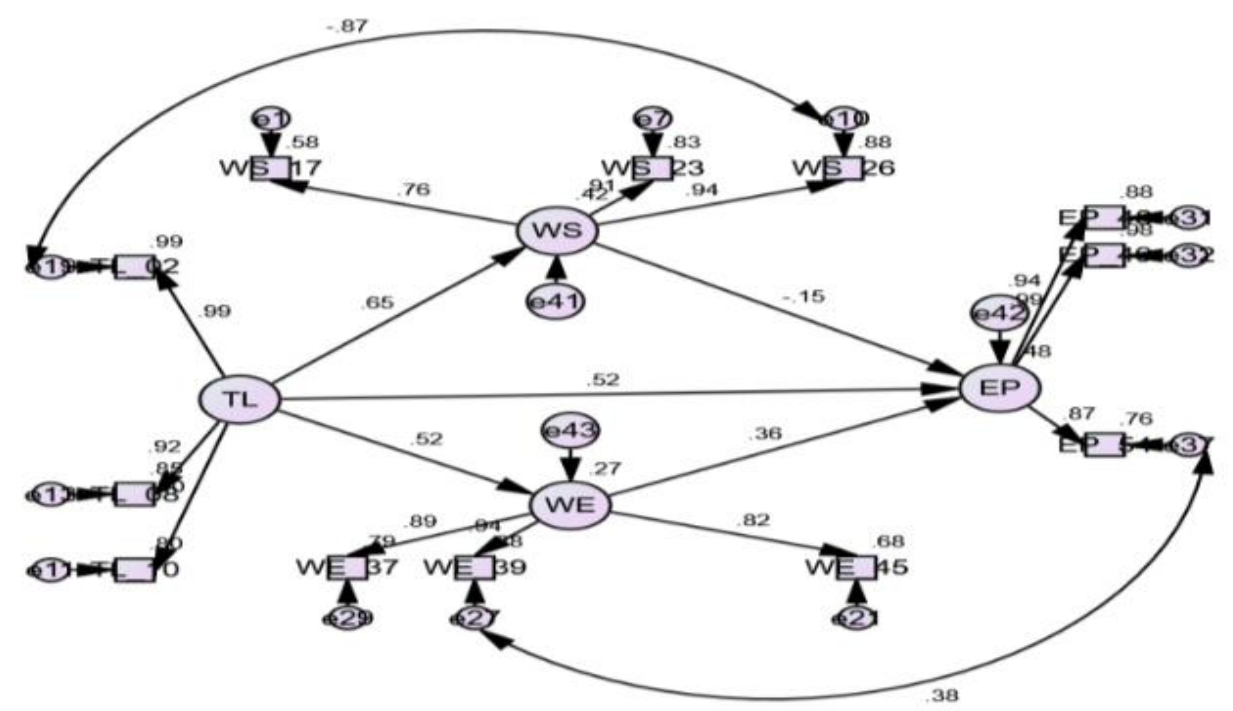

Gambar 3. Full Model Pengaruh Hubungan Antar Variabel 
mengatakan bahwa kepemimpinan transformasional dapat mempengaruhi proses dari kinerja karyawannya dan kualitas kerjanya. Menurut peneltian yang dilakukan oleh Basri (2014) mengatakan bahwa kepemimpinan transformasional memiliki pengaruh yang signifikan terhadap kinerja. Menurut penelitian yang dilakukan oleh Kovjanic (2013) menjelaskan bahwa kepemimpinan transformasional memiliki pengaruh yang signifikan terhadap kualitas kerja. Menurut penelitian yang dilakukan oleh Subekti (2013), kepemimpinan transformasional memiliki pengaruh positif terhadap kinerja karyawan. Menurut penelitian yang dilakukan oleh Abussamad (2014) yang menyatakan bahwa kepemimpinan transformasional berpengaruh secara signifikan terhadap kinerja. Dengan demikian hipotesis yang menyatakan kepemimpinan transformasional berpengaruh signifikan terhadap kinerja guru.

Uji hipotesis yang kedua ini adalah pengaruh transformasional terhadap kepuasan kerja. Dan menerangkan bahwa nilai koefisien jalur antara kepemimpinan transformasional dengan kepuasan kerja kerja sebesar 0,473 dengan nilai probabilitas sebesar 0,000. Nilai probabilitas tersebut lebih kecil dari level of signifikan yang ditetapkan $(p=0,000<a=0,05)$. Hasil pengujian ini juga didukung oleh penelitian sebelumnya yang dilakukan oleh Anggraeni dan Sentosa (2003) yang menjelaskan bahwa kepemimpinan transformasional sangat berpengaruh secara signifikan terhadap kepuasan kerja. Sedangkan penelitian yang dilakukan oleh
Nicken Aditya (2011) mengatakan bahwa kepemimpinan transformasional memberi pengaruh yang besar terhadap kepuasan karyawan di instansi kerjanya yang berdampak pada peningkatan kualitas kerja karyawan tersebut. Selanjutnya penelitian yang dilakukan oleh Dewi dan Subudi (2010) mengatakan bahwa kepemimpinan transformasional memberi dampak yang signifikan terhadap kepuasan kerja seseorang. Menurut Metwally dan Bishbishy (2014) menjelaskan bahwa kepemimpinan transformasional berpengaruh secara signifikan terhadap kepuasan kerja. Dengan demikian hipotesis yang menyatakan Kepemimpinan Transformasional berpengaruh signifikan terhadap Kepuasan kerja.

Uji hipotesis yang ketiga adalah pengaruh kepuasan kerja terhadap kinerja guru dan menjelaskan bahwa nilai koefisien jalur antara kepuasan kerja dengan kinerja guru sebesar -0,125 dengan nilai probabilitas sebesar 0,060. Nilai probabilitas tersebut lebih besar dari level of signifikan yang ditetapkan $(p=0,060>a=0,05)$. Hasil pengujian ini juga didukung oleh penelitian sebelumnya yang dilakukan oleh Nur Abidin (2010) yang menjelaskan bahwa dalam penelitian tersebut dikatakan bahwa kepuasan kerja memiliki pengaruh terhadap kinerja, akan tetapi tidak terlalu signifikan dan tidak terlalu mempengaruhi variabel kinerja. Dengan demikian hipotesis yang menyatakan kepuasan kerja tidak berpengaruh signifikan terhadap kinerja guru.

Tabel 5. Hasil Hipotesis Penelitian Direct effect.

\begin{tabular}{|c|c|c|c|c|c|}
\hline \multicolumn{3}{|c|}{ Hubungan antar Variabel } & \multirow{2}{*}{\begin{tabular}{|c|c|c}
$\begin{array}{c}\text { Koef. } \\
\text { Jalur } \\
\text { Standar } \\
\text { dize }\end{array}$ \\
0,473
\end{tabular}} & \multirow{2}{*}{$\begin{array}{c}\text { p-value } \\
0,000\end{array}$} & \multirow{2}{*}{$\begin{array}{c}\text { Ket } \\
\text { Signifikan }\end{array}$} \\
\hline $\begin{array}{l}\text { Kepemimpinan } \\
\text { Transformasional }\end{array}$ & $\longrightarrow$ & $\begin{array}{l}\text { Kepuasan } \\
\text { Kerja }\end{array}$ & & & \\
\hline $\begin{array}{l}\text { Kepemimpinan } \\
\text { Transformasional }\end{array}$ & $\rightarrow$ & $\begin{array}{l}\text { Keterikatan } \\
\text { Kerja }\end{array}$ & 0,339 & 0,000 & Signifikan \\
\hline Kepuasan Kerja & $\rightarrow$ & $\begin{array}{l}\text { Kinerja } \\
\text { Guru }\end{array}$ & $-0,125$ & 0,060 & $\begin{array}{c}\text { Tidak } \\
\text { Signifikan }\end{array}$ \\
\hline Keterikatan Kerja & $\longrightarrow$ & $\begin{array}{l}\text { Kinerja } \\
\text { Guru }\end{array}$ & 0,342 & 0,000 & Signifikan \\
\hline $\begin{array}{l}\text { Kepemimpinan } \\
\text { Transformasional }\end{array}$ & $\rightarrow$ & $\begin{array}{l}\text { Kinerja } \\
\text { Guru }\end{array}$ & 0,321 & 0.000 & Signifikan \\
\hline
\end{tabular}


Untuk hipotesis yang keempat adalah pengaruh kepemimpinan transformasional terhadap kinerja guru yang di mediasi oleh kepuasan kerja. Ini menjelaskan bahwa nilai koefisien jalur antara kepemimpinan terhadap kinerja yang dimediasi oleh kepuasan kerja sebesar 0,057. Kepemimpinan transformasional berpengaruh signifikan terhadap kepuasan kerja, tetapi kepuasan kerja tidak berpengaruh signifikan terhadap kinerja, dan koefisien jalur yang dihasilkan lebih kecil daripada koefisien jalur dari pengaruh langsung lingkungan kerja terhadap kinerja yang juga berpengaruh tidak signifikan. Kepuasan kerja merupakan mediasi sebagian atau partial mediation dari hubungan antara kepemimpinan dengan kinerja.

Hasil pengujian ini juga didukung oleh penelitian sebelumnya yang dilakukan oleh Siswanti dan Krisnandini (2012) yang mengatakan bahwa kepemimpinan transformasional memiliki pengaruh terhadap kinerja yang dimediasi oleh kepuasan kerja, akan tetapi tidak memiliki pengaruh yang terlalu signifikan. Oleh karena itu, kepuasan kerja tidak berperan dengan baik dalam memediasi pengaruh antara kepemimpinan terhadap kinerja guru.

Untuk uji hipotesis yang kelima adalah pengaruh transformasional terhadap keterikatan kerja. Adapun nilai koefisien jalur antara kepemimpinan transformasional dengan keterikatan kerja sebesar 0,339 dengan nilai probabilitas sebesar 0,000. Nilai probabilitas tersebut lebih kecil dari level of signifikan yang ditetapkan $(\mathrm{p}=0,000<$ $a=0,05)$. Hasil pengujian ini juga didukung oleh penelitian sebelumnya yang dilakukan oleh Bezuidenhout dan Schultz(2010) yang mengatakan bahwa kepemimpinan transformasional memberikan pengaruh yang positif dan signifikan terhadap keterikatan kerja seseorang terhadap pekerjaannya. Menurut penelitian yang dilakukan oleh Rizkiyan dan Nurnida (2013), menjelaskan bahwa salah satu indikator meningkatnya keterikatan kerja seseorang terhadap pekerjaaannya antara lain adalah kepemimpinan transformasional dan kepemimpinan transforamsional itu sendiri telah memberikan pengaruh yang cukup besar bagi keterikatan kerja seseorang terhadap pekerjaannya. Menurut penelitian yang dilakukan oleh Charkaby dan Naami (2014) yang menyatakan bahwa kepemimpinan transformasional berpengaruh secara signifikan terhadap keterikatan kerja. Dengan demikian hipotesis yang menyatakan Kepemimpinan Transformasional berpengaruh signifikan terhadap Ketertarikan Kinerja.

Untuk hipotesis keenam adalah pengaruh keterikatan kerja terhadap kinerja guru. Ini menjelaskan bahwa nilai koefisien jalur antara keterikatan kerja dengan kinerja guru sebesar 0,342 dengan nilai probabilitas sebesar 0,000. Nilai probabilitas tersebut lebih kecil dari level of signifikan yang ditetapkan $(p=0,000<a=0,05)$. Hasil pengujian ini juga didukung oleh penelitian sebelumnya yang dilakukan oleh Sami'an (2010) yang mengatakan bahwa keterikatan kerja akan berdampak positif pada kinerja. Menurut penelitian yang dilakukan oleh Ramadhan dan Sembiring (2011), menjelaskan bahwa keterikatan kerja berpengaruh secara signifikan dan memberikan pengaruh yang baik pada kinerja, sedangkan

Tabel 6

Hasil Hipotesis Penelitian Indirect Effect

\begin{tabular}{lllll}
\hline $\begin{array}{c}\text { Variabel } \\
\text { Independen }\end{array}$ & $\begin{array}{c}\text { Variabel } \\
\text { Intervening }\end{array}$ & $\begin{array}{c}\text { Variabel } \\
\text { Dependen }\end{array}$ & $\begin{array}{c}\text { Koef. } \\
\text { Jalur } \\
\text { Standar } \\
\text { Dize }\end{array}$ & Kesimpulan \\
\hline $\begin{array}{l}\text { Kepemimpinan } \\
\text { Transformasial }\end{array}$ & $\begin{array}{l}\text { Kepuasan } \\
\text { Kerja }\end{array}$ & $\begin{array}{l}\text { Kinerja } \\
\text { Guru }\end{array}$ & 0,057 & $\begin{array}{l}\text { Tidak } \\
\text { Signifikan }\end{array}$ \\
Transfomimpinan & Keterikatan & Kinerja & 0,092 & $\begin{array}{l}\text { Tidak } \\
\text { Gura }\end{array}$ \\
\hline
\end{tabular}


penelitian yang dilakukan oleh Annisa dan Sailing (2011) menyatakan bahwa keterikatan kerja berpengaruh secara signifikan terhadap kinerja. Dengan demikian hipotesis yang menyatakan Ketertarikan Kerja berpengaruh signifikan terhadap kinerja guru.

Untuk hipotesis yang terakhir menjelaskan bahwa nilai koefisien jalur antara kepemimpinan terhadap kinerja yang dimediasi oleh keterikatan kerja sebesar 0,057 . Kepemimpinan transformarsional berpengaruh signifikan terhadap keterikatan kerja, dan keterikatan kerja berpengaruh signifikan terhadap kinerja, dan koefisien jalur yang dihasilkan lebih kecil daripada koefisien jalur dari pengaruh langsung lingkungan kerja terhadap kinerja yang juga berpengaruh tidak signifikan. Keterikatan kerja merupakan mediasi sebagian atau partial mediation dari hubungan antara kepemimpinan dengan kinerja. Hasil pengujian ini juga didukung oleh penelitian sebelumnya yang dilakukan oleh Giovanni (2011) menyatakan bahwa terdapat pengaruh yang signifikan antara kepemimpinan transformasional terhadap kinerja guru yang dimediasi oleh keterikatan kerja. Begitu pula dengan penelitian yang dilakukan oleh Kovjanic (2013) yang menyatakan kinerja akan baik jika terdapat kepemimpinan transformasional didalamnya dan diperkuat oleh keterikatan kerja sebagai variabel mediasi sehingga memberikan pengaruh secara signifikan antara kepemimpinan transformasional terhadap kinerja yang di mediasi oleh keterikatan kerja. Menurut penelitian yang dilakukan oleh Novel (2016) menyatakan bahwa kepemimpinan transformasional memiliki pengaruh secara signifikan terhadap kinerja yang dimediasi oleh keterikatan kerja. Oleh karena itu, hipotesis yang menyatakan keterikatan kerja berperan memediasi pengaruh antara kepemimpinan transformasial terhadap kinerja guru.

\section{KESIMPULAN DAN SARAN}

Berdasarkan analisis hasil penelitian dan pembahasan tentang pengaruh kepemimpinan transformasional, yang di mediasi oleh keterikatan kerja dan kepuasan kerja dan implikasinya pada kinerja guru pada Sekolah Menengah Swasta di Wilayah Rayon 05 Jakarta Timur 1 maka dapat ditarik kesimpulan sebagai berikut: Pertama, terdapat pengaruh kepemimpinan tramsformasional terhadap kinerja guru. Nilai koefisien jalur antara Kepemimpinan Transformasional dengan Kinerja Guru sebesar 0,321 dengan nilai probabilitas sebesar 0,000 . Nilai probabilitas tersebut lebih kecil dari level of signifikan yang ditetapkan $(p=0,000<\alpha=0,05)$. Hasil pengujian ini juga didukung oleh penelitian sebelumnya yang dilakukan oleh Abbasi dan Zamani-Miandashti (2013), Basri (2014), Kovjanic (2013), Subekti (2013), Abussamad (2014) yang menyatakan bahwa kepemimpinan transformasional berpengaruh secara signifikan terhadap kinerja. Dengan demikian hipotesis yang menyatakan Kepemimpinan Transformasional berpengaruh signifikan terhadap Kinerja Guru, diterima.

Kedua, terdapat pengaruh kepemimpinan transformasional terhadap kepuasan kerja, di mana nilai koefisien jalur sebesar 0,473 dengan nilai probabilitas sebesar 0,000 . Nilai probabilitas tersebut lebih kecil dari level of signifikan yang ditetapkan $(p=0,000<\alpha=0,05)$. Hasil pengujian ini juga didukung oleh penelitian sebelumnya yang dilakukan oleh Anggraeni dan Sentosa (2003), Nicken Aditya (2011), Dewi dan Subudi (2010), Metwally dan Bishbishy (2014) yang menjelaskan bahwa kepemimpinan transformasional berpengaruh secara signifikan terhadap kepuasan kerja. Dengan demikian hipotesis yang menyatakan Kepemimpinan transformasional berpengaruh signifikan terhadap kepuasan kerja, diterima.

Ketiga terdapat pengaruh kepuasan kerja terhadap kinerja guru dengan nilai koefisien jalur sebesar -0,125 dengan nilai probabilitas sebesar 0,060 . Nilai probabilitas tersebut lebih besar dari level of signifikan yang ditetapkan $(p=0,060>\alpha=0,05)$. Hasil pengujian ini juga didukung oleh penelitian sebelumnya yang dilakukan oleh Nur Abidin (2010) yang menjelaskan bahwa dalam penelitian tersebut dikatakan bahwa kepua- 
san kerja memiliki pengaruh terhadap kinerja, akan tetapi tidak terlalu signifikan dan tidak terlalu mempengaruhi variabel kinerja. Dengan demikian hipotesis yang menyatakan kepuasan kerja berpengaruh signifikan terhadap kinerja guru , tidak diterima.

Keempat, terdapat pengaruh kepemimpinan transformasional terhadap kinerja guru yang di mediasi oleh kepuasan kerja, di mana nilai koefisien jalur sebesar 0,057. Kepemimpinan transformasional berpengaruh signifikan terhadap kepuasan kerja, tetapi kepuasan kerja tidak berpengaruh signifikan terhadap kinerja, dan koefisien jalur yang dihasilkan lebih kecil daripada koefisien jalur dari pengaruh langsung lingkungan kerja terhadap kinerja yang juga berpengaruh tidak signifikan. Kepuasan kerja merupakan mediasi sebagian atau partial mediation dari hubungan antara kepemimpinan dengan kinerja. Hasil pengujian ini juga didukung oleh penelitian sebelumnya yang dilakukan oleh Siswanti dan Krisnandini (2012) yang mengatakan bahwa kepemimpinan transformasional memiliki pengaruh terhadap kinerja yang dimediasi oleh kepuasan kerja, akan tetapi tidak memiliki pengaruh yang terlalu signifikan. Oleh karena itu, hipotesis yang menyatakan kepuasan kerja berperan memediasi pengaruh antara kepemimpinan terhadap kinerja guru, tidak diterima.

Kelima, terdapat pengaruh kepemimpinan transformasional terhadap keterikatan kerja dengan nilai koefisien jalur sebesar 0,339 dengan nilai probabilitas sebesar 0,000 . Nilai probabilitas tersebut lebih kecil dari level of signifikan yang ditetapkan $(p=0,000<a=0,05)$. Hasil pengujian ini juga didukung oleh penelitian sebelumnya yang dilakukan oleh Bezuidenhout dan Schultz (2010), Rizkiyan dan Nurnida (2013), Charkaby dan Naami (2014) yang menyatakan bahwa kepemimpinan transformasional berpengaruh secara signifikan terhadap keterikatan kerja. Dengan demikian hipotesis yang menyatakan Kepemimpinan Transformasional berpengaruh signifikan terhadap Ketertarikan Kinerja ,diterima.

Keenam, terdapat pengaruh keterikatan kerja terhadap kinerja guru dengan nilai koefisien jalur sebesar 0,342 dengan nilai probabilitas sebesar 0,000 . Nilai probabilitas tersebut lebih kecil dari level of signifikan yang ditetapkan $(\mathrm{p}=0,000<\mathrm{a}=0,05)$. Hasil pengujian ini juga didukung oleh penelitian sebelumnya yang dilakukan oleh Sami'an (2010), Ramadhan dan Sembiring (2011), Annisa dan Sailing (2011) yang menyatakan bahwa keterikatan kerja berpengaruh secara signifikan terhadap kinerja. Dengan demikian hipotesis yang menyatakan ketertarikan kerja berpengaruh signifikan terhadap kinerja guru diterima.

Ketujuh, kepemimpinan transformarsional berpengaruh signifikan terhadap keterikatan kerja, dan keterikatan kerja berpengaruh signifikan terhadap kinerja, dan koefisien jalur yang dihasilkan lebih kecil daripada koefisien jalur dari pengaruh langsung lingkungan kerja terhadap kinerja yang juga berpengaruh tidak signifikan. Keterikatan kerja merupakan mediasi sebagian atau partial mediation dari hubungan antara kepemimpinan dengan kinerja. Hasil pengujian ini juga didukung oleh penelitian sebelumnya yang dilakukan oleh Giovanni (2011), Kovjanic (2013), Novel (2016) yang menyatakan bahwa kepemimpinan transformasional memiliki pengaruh secara signifikan terhadap kinerja yang dimediasi oleh keterikatan kerja. Oleh karena itu, hipotesis yang menyatakan keterikatan kerja berperan memediasi pengaruh antara kepemimpinan transformasial terhadap kinerja guru diterima.

Dari hasil penelitian di atas maka disarankan sekolah menengah swasta yang berada di wilayah rayon 05 Jakarta Timur 1 harus mampu memberikan solusi dalam mengatasi permasalahan kinerja karyawan ini sebaik mungkin, karena tidak ada sekolah manapun yang tidak terdapat permasalahan terutama dalam hal kinerja di dalamnya. Untuk itu setiap lini terutama kepala sekolah harus mampu membawa sekolah tersebut ke arah yang lebih baik dengan cara meningkatkan kinerja para tenaga pendidiknya serta kualitas tenaga pendidiknya.

Sebagaimana dijelaskan di atas bah- 
wa banyak hal yang akan mempengaruhi kinerja karyawan maka faktor kepemimpinan kerja yang ditimbulkan oleh kepala sekolah terhadap tenaga pendidiknya begitu penting, tidak lain juga faktor kepuasan kerja kerja penelitian menunjukan bahwa kepuasan kerja akan berdampak langsung terhadap kinerja karyawan, maka hal ini perlu diperhatikan seperti memberikan solusi dalam hal penerimaan gaji, tunjangan dan bonus untuk tenaga pendidik. Keterikatan kerja kerja juga berperan penting terhadap kinerja guru, karena apabila guru merasa terikat dengan pekerjaannya, maka guru tersebut akan mampu dalam peningkatan kualitas kerjanya. Agar kedepannya tidak muncul kembali dalam hal kinerja guru.

Bagi peneliti selanjutnya, keluasan dalam menggunakan variabel begitu amat penting menentukan hasil yang dapat meingkatkan kinerja guru, kemampuan membuat kuesioner menjadi hal terpenting selanjutnya untuk mendapatkan hasil yang akurat. Kemampuan responden dalam menjawab kuesioner secara baik menjadi amat penting dan diperlukan, tidak sedikit dari mereka mengisi dengan tidak baik sehingga hasil kuesioner menjadi tidak maksimal, agar hasil yang didapat juga memberikan dampak yang baik dalam menyajikan kesimpulan, oleh karenanya peneliti selanjutnya diharapkan mampu merampungkan teori sebanyakbanyaknya terkait apa saja variabel yang dibutuhkan untuk menggambarkan variabel teramati lebih sempurna, dan informasi tersebut bisa kita lihat dari jurnal yang diterbitkan peneliti terdahulu dan referensi bukubuku yang berkaitan dengan kinerja karyawan.

Masih banyak sekali variabel dengan tingkat uji coba hasil yang baik dan signifikan untuk penelitian selanjutnya. Maka disarankan usaha dan kerja keras peneliti selanjutnya dalam mendalami variabelvariabel yang teramati amat penting, maka sangat dibutuhkan kedalaman teori dan pengamatan yang ekstra lebih besar agar dapat menentukan variabel yang lebih baik dan dapat mengumpulkan informasi lebih akurat dan dipertanggungjawabkan.

\section{DAFTAR PUSTAKA}

Abbasi, Enayat and Naser ZamaniMiandashti. (2013). The Role Of Transformational Leadership, Organizational Culture And Organizational Learning In Improving The Performance Of Iranian Agricultural Faculties. High Educ 66, Hal 505-519

htpp://hdr.undp.org/en/content/humandevelopment-report-2013, diakses tanggal 1 November 2015

http://www.weforum.org/docs/ WEF GlobalCompetitivenessReport 2 014-15.pdf, diakses pada tanggal 1 November 2015

Khan, A. H., Nawaz, M. M., Aleem, M., \& Hamed, W. (2012). Impact of job satisfaction on employee performance: an empirical study of autonomous medical institutions of pakistan. African journal of business management, 6(7), 2697-2705.

Kovjanic, Snjezana. (2013). Transformational Leadership And Performance: An Experimental Investigation Of The Mediating Effects Of Basic Needs Satisfaction And Work Engagement. Journal Of Occupational And Organizational Psychology 86, Hal. 543-555

Laka, Tarsisius Senggo. (2013). Pengaruh Kecerdasan Emosial dan Work Engagement terhadap Komitmen Organisasi pada Karyawan Credit Union Kasih Sejahtera Atambua. Tesis. Universitas Atma Jaya Yogyakarta. Yogyakarta.

Macey, William H. dan Benjamin Schneider. (2008). The Meaning of Employee Engagement, Jurnal Industrial and Organizational Psychology, Vol 1, Hal.330.

Metwally, Ayman H. And Nada El-Bishbishy. (2014).The Impact Of Transformational Leadership Style On Employee Satisfaction. The Business \& Management Review, Volume 5 Number 3. 3242.

Mondy, Wayne R. (2003). Human Resource Management. New Jersey: Person Ed- 
ucation.

Nurcahyani, N. M., \& Idnyani, I. D. (2016). Pengaruh kompensasi dan motivasi terhadap kinerja karyawan dengan kepuasan kerja sebagai variabel intervening. E-jurnal manajemen UNUD, 5(1), 500-532.

Pambudi, Didit Setyo. (2006). Pengaruh Gaya Kepemimpinan Transformasional Terhadap Kinerja Karyawan Melalui Kepuasan Kerja Karyawan Sebagai Variabel Mediasi. Jurnal Administrasi Bisnis (JAB)|Vol. 39 No. 1,164-170

Platis, C. H., Reklitis, P., \& Zimeras, S. (2014). Relation between job satisfaction and job performance in healthcare services. Social and behavioral science, 175, 480-487.

Platis, C. H., Reklitis, P., \& Zimeras, S. (2014). Relation between job satisfaction and job performance in healthcare services. Social and behavioral science, 175, 480-487.

Schein, H. E. (2004). Organizational culture and leadership (3rd ed.). San Francisco:

Senge, P., Roberts, C., Ross, R. B., Smith, B. J., \& Kleiner, A. (1994). The fifth discipline fieldbook. New York: Doubleday Publ.

Sporn, B. (2003). The dialogue between higher education research and practice. Netherlands: Springer.

Sumakto, Windy Auliah \& Sami'an. (2013). Hubungan Keterikatan Kerja dengan Kinerja pada Karyawan Hotel Surabaya Plaza. Jurnal Psikologi Industri dan Organisasi. Vol. 2 No. 2. 1-6

Ulrich, D., Von Glinow, M. A., \& Jick, T. (1993). High-impact learning: Building and diffusing learning capability. 